\title{
EU Policy on Equality between Homo- and Heterosexuals and Cititzens' Attitudes toward Homosexuality in 26 EU Member States and Turkey.
}

\author{
Jürgen Gerhards
}

Berliner Studien zur Soziologie Europas

Nr. 8

März 2007 
Die „Berliner Studien zur Soziologie Europas“ des Lehrstuhls für Makrosoziologie der Freien Universität Berlin verstehen sich als ein Ort zur Vorpublikation von Beiträgen, die später in Fachzeitschriften und Sammelbänden veröffentlicht werden sollen. Die Beiträge sollen helfen, eine Soziologie Europas zu profilieren; sie stehen auch im Kontext des Master-Studiengangs „Soziologie - Europäische Gesellschaften“.

Gegenstand der Reihe sind Beiträge zur Analyse der Herausbildung einer europäischen Gesellschaftsstruktur und -kultur, vergleichende Analysen, die die Unterschiede und Gemeinsamkeiten zwischen verschiedenen europäischen Gesellschaften thematisieren, sowie theoretische Versuche einer Soziologie Europas.

Ziel der Reihe ist es, durch die frühe Verbreitung dieser Arbeiten den wissenschaftlichen Gedankenaustausch zu fördern. Die Beiträge sind nur über das Internet als pdf-Datei zu beziehen.

Zitationsweise: BSSE-Arbeitspapier Nr. 8. Berlin: Freie Universität Berlin. 


\begin{abstract}
The article first describes how the principle of non-discrimination of homosexuals is anchored in EU legislation and influences concrete policies of the European Union. The second section gives an analysis of the extent to which citizens of 26 EU Member States and Turkey support the idea of non-discrimination of homosexuals.

The descriptive findings show that the idea of non-discrimination is not supported by the majority of the European citizens, and that there are substantial differences between the countries. A sense that homosexuality is justifiable is particularly low in recently-acceded country groups, and is almost nonexistent in Turkey. In the third section, we explain these differences by referring, among other factors, to the level of modernization of a country, the value orientation of the respondent, the level of education and the religious orientation of the respondent. The results show, that a high level of modernization, the interviewee's level of education, and post-materialist values have the strongest impact on non-discrimination attitudes. One may therefore conclude that support for non-discrimination toward homosexuals will increase if new member states go through a period of modernization similar to that of the old member states.
\end{abstract}


Jose Barroso's term in office as President of the European Commission began with a massive conflict between the future commissioner and the European Parliament. ${ }^{1}$ After Barroso was nominated by the governments of the member states, he and his hand-picked team of commissioners were to be confirmed by the European Parliament in fFall 2004. Italian Rocco Buttiglione was one of Barroso's selected commissioners, nominated to serve as Vice President of the Commission, responsible for Justice, Freedom and Security. During an EU parliamentary hearing on October $10^{\text {th }}$, 2004, Buttiglione - professor of philosophy, avowed Christian, member of the Pontifical Academy of Social Sciences and personal consultant to Pope John Paul II caused a public stir and precipitated a crisis in the still unconfirmed commission by expressing his views on homosexuality and the role of women in society. ${ }^{2}$ In light of his Catholic convictions, Buttiglione expressed his belief that homosexuality is a sin. In the same hearing, however, he also referred to Kant, saying "that there is a clear distinction between morality and law" (European Parliament 2004). Buttiglione emphasized that his personal moral convictions would not prevent him from representing EU non-discrimination policies regarding homosexuals. Public debate, however, is generally not receptive to such philosophical differences. Hence, the European Parliament rejected Barosso's commission, an unprecedented occurrence in EU history. Barroso was forced to select new commissioners; Buttiglione was replaced by Franco Frattini, who was then confirmed by the Parliament on November $18^{\text {th }}, 2004$.

Parliament's rejection of Buttiglione and, by extension, of the entire Barroso Commission cannot be written off as a mere power struggle between the European Commission and Parliament. Rather, the Buttiglione Affair revolved around the actual content of policies that the EU represents, namely non-discrimination toward homosexuals.

The European Union began as an economic union, but has become active in an increasing number of other policy fields over time. In pursuing its goal of creating a single European society, the central institutions of the EU intervene evermore into national structures of the member states. We have described in other works how the EU defines this unified European society in terms of a number of value spheres, such as religion, family and gender roles, democracy and civil society (Gerhards und Hölscher 2003; Gerhards 2005/2007; Hölscher 2006; Gerhards und Lengfeld 2006). This contribution ties in to our overall analysis.

\footnotetext{
${ }^{1}$ I would like to thank David Glowsky, who expertly compiled the information on EU policies. I would also like to thank Silke Hans and Kristin Haker for their solid and dependable data analysis. Last, but not least, thanks goes to Joana Schenke for her very in-depth revision of the translation.

2 Public outcry was reflected by a high level of media attention. In an attempt to reconstruct the news coverage surrounding the Buttiglione Affair, we counted the number of related articles that appeared in the online editions of "Die Welt", "Süddeutsche Zeitung", "Le Monde" and in BBC-News. In Fall 2004, ninety-seven articles appeared in "Le Monde", ninety-two in "Die Welt", thirty-four in the "Süddeutsche Zeitung", and thirty-six in BBC-News.
} 
The EU has also developed ideas about which forms of sexuality should be considered legitimate. Homosexual and heterosexual orientations are considered equal, and discrimination against homosexuality is forbidden. We first reconstruct how the principle of non-discrimination is anchored in EU legislation and discuss the influence this has on concrete policies and decisions. Against this background, we then focus on our research question, which asks to what extent citizens in different nationstates support the notion of non-discrimination toward homosexuals. The second section of the article analyzes the extent to which citizens support the idea of nondiscrimination and whether there are differences among EU member states. The empirical basis used to reconstruct the citizens' value orientations is a secondary analysis of the European Values Study, a representative survey conducted in EU member states and candidate countries. Citizens' acceptance and support of EU regulations is significant, especially in terms of the legitimacy of EU policies owing to the fact that democracies are structurally dependent on the support of their citizens (Page and Shapiro1983). If this support is missing, legitimacy problems may arise for the institutions themselves. ${ }^{3}$

The descriptive findings show that there are substantial differences at the national and individual level in the level of support for non-discrimination toward homosexuals. In the third section, we offer some explanations for these differences by formulating hypotheses and testing them with a regression analysis. In the last section we discuss conclusions drawn from our analysis, paying special attention to the implications for the future development of the European Union.

\section{EU Policy on Equality between Homo- and Heterosexuals}

In order to reconstruct the EU notion of equal treatment for homo- and heterosexuals, we interpreted treaties, directives, regulations and recommendations released by EU institutions. These sources range from the abstract, such as treaties, to concrete policies. Matteo Bonini-Baraldi (2004) has collected, summarized and published all legally-binding rules concerning homo- and heterosexual issues in the EU, and we will rely heavily on his work.

1. The EU began as an economic community whose foremost goal was to institutionalize a common market for all member states. A central goal since the beginning of this project has been to create equal access to the market for all Europeans. One aspect of free access to the market includes prohibiting any sort of discrimination that would block a member citizen's ability to participate. Thus, we find for example the principle of equal pay for men and women in the EC in Article 119 of the 1957

\footnotetext{
${ }^{3}$ One example of this legitimacy deficit was the May 2005 French and Dutch rejection of the European Constitution; the elite project of giving Europe a new constitution failed after citizens of two member states refused to support the idea.
} 
Treaties of Rome. The basis for non-discrimination continually expanded with the development of the EU, and more personal characteristics were included as possible grounds for discrimination. The European Court of Justice ruled that "Article 141 of the EC Treaty pursues both economic and social objectives and may be viewed as a guarantee for social progress" (Bonini-Baraldi 2004: 8). The 1999 Treaty of Amsterdam includes Article 13, which states that: "(1) Without prejudice to the other provisions of the Treaty and within the limits of the powers conferred by it upon the Community, the Council, acting unanimously on a proposal from the Commission and after consulting the European Parliament, may take appropriate action to combat discrimination based on sex, racial or ethnic group, religion or belief, disability, age or sexual orientation" (Bonini-Baraldi 2004: 8). With Article 13, the EU's antidiscrimination principle was extended in two key ways. First, this was the first mention of "sexual orientation" in terms of anti-discrimination policy. Second, the European Commission and the European Council were given the power to create guidelines to fight discrimination. Article III-21 of the Charter of Fundamental Rights of the European Union also prohibits discrimination on the basis of sexual orientation and serves as firm legal anchor for equality between homosexuals and heterosexuals in the EU (European Community 2000).

2. Directly after the implementation of Article 13 in the Treaty of Amsterdam, the Commission developed a directive, which was passed by the 2000 Council. The “Council Directive 2000/78/EC of 27 November 2000 establishing a general framework for equal treatment in employment and occupation" very clearly defines what is considered as discrimination (European Council 2000), and discrimination on the basis of sexual orientation is a part of the general directive. Article 2 of the directive distinguishes between direct and indirect discrimination: "(a) Direct discrimination shall be taken to occur where one person is treated less favourably than another is, has been or would be treated in a comparable situation, on any of the grounds referred to in Article 1; (b) indirect discrimination shall be taken to occur where an apparently neutral provision, criterion or practice would put persons having a particular religion or belief, a particular disability, a particular age, or a particular sexual orientation at a particular disadvantage compared with other persons". The directive spells out a number of concrete policies that define equality between homo- and heterosexuals, which have been summarized by Matteo Bonini-Baraldi (2004). The EU anti-discrimination regulations have since been incorporated into the national legislation of the member states; homosexuality is no longer considered criminal in any EU member state, and anti-discrimination is legally anchored in all countries.

3. The EU principle of non-discrimination toward homosexuals also applies to new member states, a natural consequence of their taking on the acquis communautaire. Negotiations with Romania are a good example with which to show the implementation of the EU's policy of equality for homosexuals in new member states. Until 1996 homosexuality was punishable by law under the Romanian Criminal Code. Article 200 stated: "Sexual relations between persons of the same sex are punishable 
by a prison term between one and 5 years" (Human Rights Watch 1988). A new penal code came into force in November 1996, in which the first paragraph of the article was amended to read as follows: "Sexual relations between persons of the same sex, committed in public or producing a public scandal, are punishable by a prison term between one and 5 years". With this change, private homosexual activity was legalized, but was still considered criminal under certain circumstances. The wording "committed in public or producing a public scandal" was added as a compromise between those who wanted keep the existing legislation and those who wanted the entire article repealed. But even in its amended form, Article 200 was again repealed again due to pressure from various organisations. One key factor in the appeal was the pressure from the EU, which stated that all laws discriminating against homosexuality must be abrogated for Romania to become a full member of the EU. The Council also criticised the law as a stain on Romania's human rights record. This led to the article's repeal in June 2001, when the government adopted Emergency Ordinance 89/2001 modifying the Penal Code and removing Article 200 completely.

4. The European Union has also turned equality between homosexuals and heterosexuals into a foreign policy issue. To give two examples, we look at Namibia and Egypt. On April 5 ${ }^{\text {th }}, 2001$ the European Parliament held an inquiry into the persecution of gays and lesbians in Namibia; Parliament addressed the issue by denouncing the "vilification and persecution of persons for their sexuality" (European Parliament 2001). And on July 3 ${ }^{\text {rd }}, 2002$ Parliament held another inquiry into the arrest of fifty homosexual men in Egypt. Again, the Parliament criticized the actions of the Egyptian judicial system (European Parliament 2002).

To summarize our findings, non-discrimination toward homosexuals was not part of the Treaties of Rome nor was it defined as an original objective of the EU. Rather, the original intent of the European Community was to establish a common market. The EU expanded its jurisdiction into other policy fields using the "frame-bridging" strategy. ${ }^{4}$ A free market exists only when all actors have the same opportunities to participate in the market and nobody is discriminated; but the question of which characteristics and attributes are grounds of discrimination remains open to interpretation. EU institutions have gradually increased the number of characteristics that might lead to discrimination, and sexual orientation is now one of these features. The reach of EU institutions into various national policy fields has expanded with the inclusion of each new protected group under the EU's non-discrimination policies; the EU has thus increased its power at the expense of the nation states. Legal equal treatment of homo- and heterosexuals in the EU was first introduced in the 1999 Treaty of Amsterdam. Since 2000, this equal treatment has been an integral part of the "Charter of Fundamental Rights of the European Union". In a non-discrimination directive, the EU Council specified exactly what the legal equal treatment of homo-

\footnotetext{
${ }^{4}$ The concept of "framing-bridging" was developed by David Snow in the context of social movement research (Snow et. al. 1986: Snow/Benford 1988).
} 
and heterosexuals entails. Subsequent political developments have shown that the $\mathrm{EU}$ is paying very close attention to ensure that member states implement this principle.

\section{Attitudes of EU citizens toward non-discrimination of homosexuals}

To what extent do EU citizens in various member states support the idea of nondiscrimination of homosexuals and the EU policy of equal treatment between homoand heterosexuals? We will analyze the value orientations of citizens through a secondary analysis of the 1999-2000 European Values Survey. ${ }^{5}$ The national samples each contain results from at least 1,000 interviews, which were conducted face-to-face with respondents over the age of eighteen and therefore constitute a representative sample for each country. The European Values Survey contains one question particularly well-suited to operationalize citizens' attitudes toward non-discrimination of homosexuals. The question is formulated as follows: "Please, tell me whether homosexuality can always be justified, never be justified or something in between." Interviewees were asked to answer this question using a 10-point scale ranging from "never" (1) to "always" (10). The following graph depicts the mean values for each country. We also differentiate between four groups of countries: the old EU member states (EU-15), member states who have acceded since May 1st, 2004 (Enlargement I), the two states that became members of the EU in 2007 (Enlargement II), and Turkey.

Diagram 1 shows that at the aggregate level, there is no clear majority approval for the idea of non-discrimination toward homosexuals. The level of rejection between groups, however, varies substantially. Whereas the mean value in the old EU member states lies around the center of the scale, justification of homosexuality in new member states is very low, and is almost entirely absent in Turkey, with a mean value of 1.6 as measured on the ten-point scale.

There are clear differences within the country groups at the national level as well. Support for non-discrimination toward homosexuals in the northern, Protestant countries Sweden, Denmark and the Netherlands is rather high; in the Catholic countries Ireland, Italy, and Portugal, support is much lower. The Czech Republic, Slovakia and Slovenia are the only new member states that come close to the mean values in the EU-15. In all other countries, especially in Turkey, nearly all citizens are of the opinion that homosexuality is unjustifiable. Even in the old EU member states, support for the EU notion of non-discrimination toward homosexuals is not very high. The admission of new countries will change the overall culture in the EU, insofar as

5 Useful information regarding the European Values Survey can be found at http://www.europeanvalues.nl. See also the work by Loek Halman (2001), The EVS data set is available at the Central Archive for Empirical Social Research in Cologne under the number 3811. 
the proportion of those who do not share the EU's concept of non-discrimination will increase substantially.

Diagram 1: Attitudes toward non-discrimination of homosexuals: "Homosexuality is never (1) / always (10) justified" (mean values)

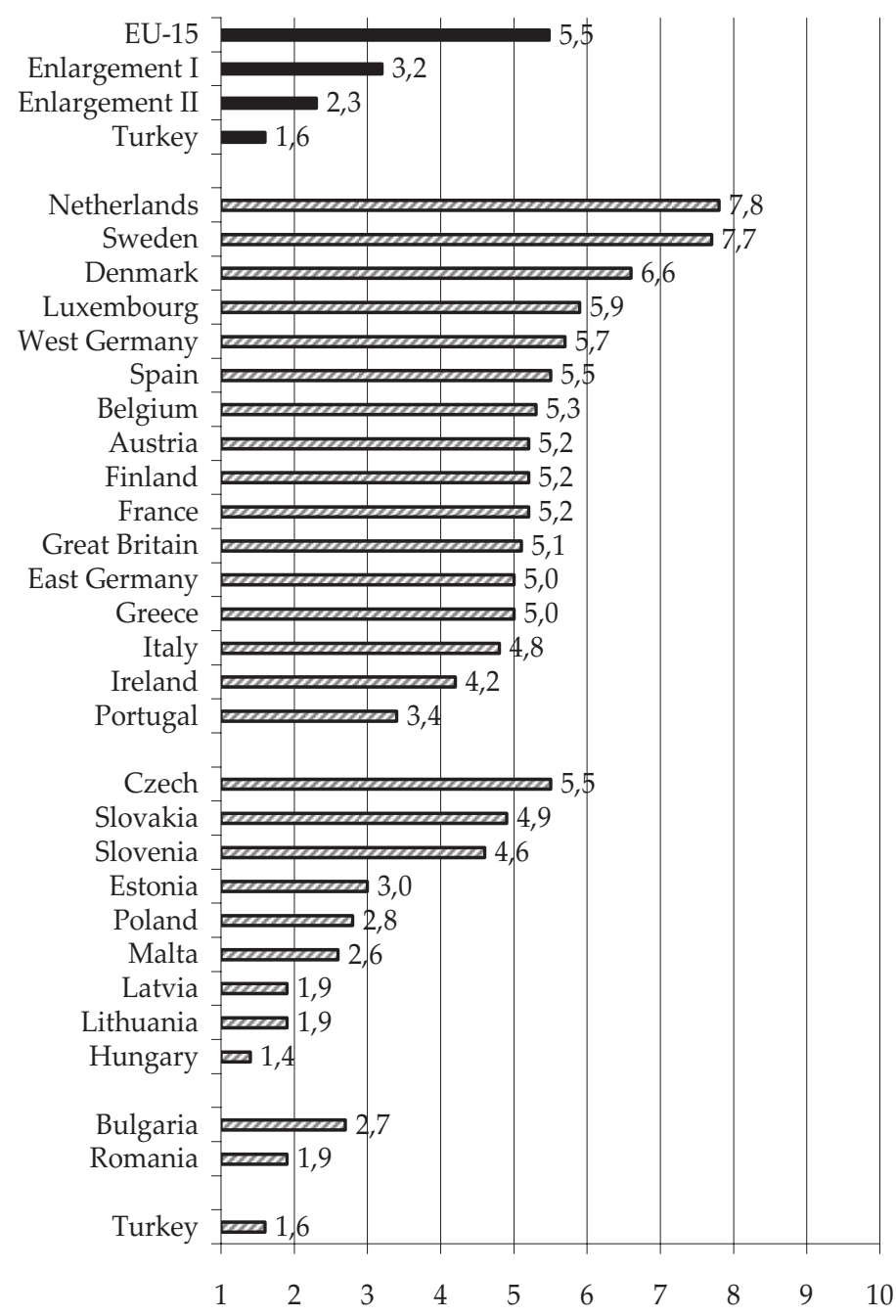

In a second question measuring non-discrimination toward homosexuals on the EVS, respondents were asked whether they would be opposed to having various minority groups as neighbours from a given list. One of these minority groups interviewees could mention were homosexuals. Diagram 2 shows the percentage of respondents in each country and country group who did not mention homosexuals as a group they would not want as neighbours.

The order of countries that did not mind having homosexuals as neighbours is quite similar to the ordering in Diagram 1. The support for non-discrimination toward homosexuals in Sweden, Denmark and Netherlands is highest, whereas support in Turkey is very low. The pattern remains similar to Diagram 1 between these two extremes as well. 
A further confirmation of our results comes from a study carried out by Jonathan Kelley (2001). Kelley analyzed data from the International Social Survey Programme (ISSP, 1998/1999), a survey carried out in twenty-nine countries. Nineteen ISSP countries are included in the EVS data set. Among other topics, the ISSP asks a question about tolerance toward homosexuality, and the resultant ordering of countries is almost identical to those in Diagrams 1 and 2. This congruence points to the reliability of our results.

Diagram 2: $\quad$ Attitudes toward non-discrimination of homosexuals: Percentage of people who do not mind having a homosexual neighbour

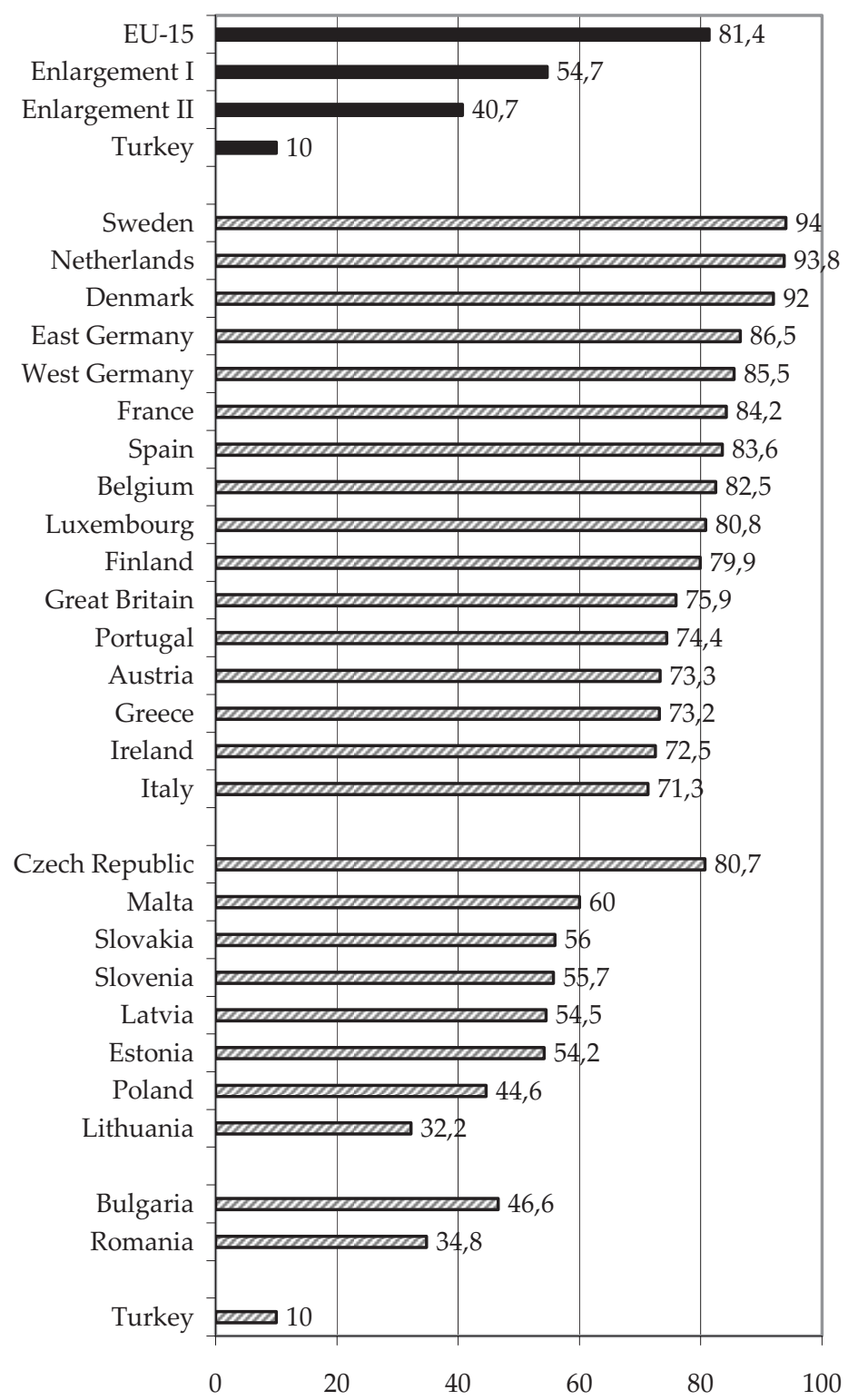




\section{Explaining attitudes of non-discrimination toward homosexuals}

The descriptive results in the last section showed that there are substantial differences between countries and individuals regarding non-discrimination toward homosexuals. In this section, we first discuss which explanatory factors might influence citizens' attitudes toward equal treatment of homo- and heterosexuals; we then empirically test whether these factors have the expected effect with a regression analysis.

\subsection{Religion}

The religious heritage of a country is an important factor that may influence its citizens' value orientations. This argument stems from Max Weber's comparative religious studies; Samuel P. Huntington makes a similar argument in his controversial work, "The Clash of Civilizations" (1996). We assume that membership in one of the main EU religious denominations (Muslim, Catholic, Lutheran-Protestant, Orthodox Christian, or no religious affiliation) will influence attitudes toward homosexuality. The various denominations have developed different interpretations of and positions toward homosexuality. We assume that these institutional interpretations influence the attitudes of their members. The more homosexuality is rejected and interpreted as deviant behaviour by a particular denomination, the more the members of that denomination will reject homosexuality.

a. Muslims: The Koran holds the ultimate authority in the Muslim faith. There is, however, no extensive commentary in the Koran about homosexuality. Only in the story of Lot, which is referred to in five passages in the Koran, does homosexuality play a central role. The most important sentence from which to conclude that the Koran forbids same-sex relations among men reads as follows: "How can you lust for males, of all creatures in the world, and leave those whom God has created for you as your mates. You are really going beyond all limits" (Duran 1993: 182). A secondary source in Islam is the Hadîth, a collection of the teachings of Prophet, passed down orally after Muhammad's death (Mohr 2003: 63; Robinson 2002). There is an array of passages in the Hadîth related to homosexuality, for example: "If you see people do as Lot's tribe did [i.e., commit homosexuality], kill both the one who does and the one who lets it be done to him" (Duran 1993: 182). Some scholars think that this applies to lesbians as well, whereas others think that lesbians should be punished less. (Duran 1993: 182). The Prophet also addressed the subject of homosexuality in his last speech to the community, known as the "Farewell Sermon." This speech contains the following statement: "Whoever has intercourse with a woman and penetrates her rectum, or with a man, or with a boy, will appear on the Last Day stinking worse than a corpse; people will find him unbearable until he enters hell fire, and God will cancel all his good deeds" (Duran 1993: 182). 
The reason for rejecting homosexuality in Islam is the same as in Christianity; namely, the purpose of sexuality is procreation. Homosexuality contradicts this purpose and is condemned as a misuse of the will of God (Duran 1993:182; Al-Fatiha Foundation 2003). The rejection of homosexuality in Islam is expressed very strongly. In most Islamic countries, homosexuality is harshly punished. Owing to the fact that Turkey is a secular republic, homosexuality is not illegal. But despite the legal protection, public expressions or displays of homosexuality remain largely taboo in the general public; in Turkish military law, homosexuality is regarded as a mental illness, and homosexuals are thereby banned from military service.

In the Christian faith, homosexual sex has historically been interpreted as sinful, based on certain passages in the Bible. This position is still affirmed by most Christian groups, including the Catholic and Orthodox Churches as well as by many Protestant denominations to varying degrees.

b. Catholics: The Catholic Church has repeatedly emphasized its opposition to homosexuality. The "Congregation for the Doctrine of the Faith" clearly reiterated this position in its most recent remarks on this topic, the "Considerations Regarding Proposals to give legal Recognition to Unions between Homosexual Persons" (Vatican 2003). The authors of the "Considerations" were Archbishop Angelo Amato and Cardinal Joseph Ratzinger, who is now the Pope of the Catholic Church. We quote from that paper: "There are absolutely no grounds for considering homosexual unions to be in any way similar or even remotely analogous to God's plan for marriage and family. Marriage is holy, while homosexual acts go against the natural moral law. Homosexual acts close the sexual act to the gift of life. They do not proceed from a genuine affective and sexual complementarity. Under no circumstances can they be approved. Sacred Scripture condemns homosexual acts 'as a serious depravity...' (cf. Rom 1:24-27; 1 Cor 6:10; 1 Tim 1:10). This judgment of Scripture does not of course permit us to conclude that all those who suffer from this anomaly are personally responsible for it, but it does attest to the fact that homosexual acts are intrinsically disordered".

The Catholic Church has used the concept of heterosexual marriage as the reference point from which to define homosexuality as amoral and as a sin. Marriage is not considered to be just any relationship between human beings, but is rather interpreted as a relationship established by the Creator with its own set of rules. Marriage exists solely between a man and a woman, in that "they mutually perfect each other, in order to cooperate with God in the procreation and upbringing of new human lives". (Vatican 2003)

c. Orthodox: Although each existing Orthodox Church is independently administered, they all share a common understanding of homosexuality (Hopko 1987). The traditional Orthodox understanding of the Old and New Testament scriptures is expressed in the Church's liturgical worship, which makes clear that the Orthodox Church considers homosexual orientation a disorder and a disease and homosexual acts as sinful and destructive. Again, the importance of marriage and the family 
serve as the reference point from which to define homosexuality as sinful. Orthodox Christian teachings on marriage and sexuality dictate that marriage consists in the conjugal union between a man and a woman, and that an authentic marriage is blessed by God as a sacrament of the Church. The union between a man and a woman in the Sacrament of marriage reflects the union between Christ and His Church. Such a holy union between persons of the same sex is neither blessed nor sanctioned by Scripture nor holy tradition. To give an example of the Orthodox Church's understanding of homosexuality, we turn to Romania. Romania's Orthodox Church was a strong advocate for keeping Article 200 as part of the Penal Code. Article 200 stated that sexual relations between persons of the same sex, committed in public or producing a public scandal, were punishable by law. The European Union put pressure on Romania to remove Article 200, but the Romanian Orthodox Church, who condemns homosexuality as a sin, urged the Romanian parliament not to remove the article. Archbishop Nifon, after a two-day meeting of senior Orthodox clerics, stated, "Our Church does not say a sexual minority should be sent to jail, [but] everybody should know that homosexuality is a sin against religious, and against family and social values, which are at the core of our Church." 6

d. Lutheran-Protestants: The national Lutheran-Protestant churches within the EU are more or less independent units, which makes it difficult to speak of the LutheranProtestant church's stance on homosexuality. We base our analysis on the Evangelical Church in Germany, whose position on homosexuality is similar to that of other European Lutheran-Protestant churches. ${ }^{7}$ The Evangelical Church in Germany (EKD) most recently gave its position on homosexuality in a statement issued in 1996. The first part summarizes two explicit statements in the Bible regarding homosexuality, which make clear that homosexuality is unacceptable. The second part emphasizes, however, that there is a higher-ranking, central commandment in the Bible: the commandment to love one another. "A relationship must be established between the commandment to love, the epitome of the holy will of God, and the question of how to ethically and responsibly address homosexual cohabitation. Because the commandment to love is unconditional and all-encompassing, homosexual cohabitation cannot be considered an exception to that rule. This means that the commandment, expressed as the holy will of God, also holds true for the homosexual way of life" (EKD 1995, 2.3, own translation). The Protestant Church therefore judges homosexual relationships as it does every other interpersonal relationship, namely by whether the relationship is characterized by love for God and for others. With this interpretation of the Bible, the contemporary Protestant Church diverges from the Catholic and

\footnotetext{
${ }^{6}$ REUTERS press release, September 132000

(http://www.sodomylaws.org/world/romania/ronews14.htm).

7 The Evangelical Lutheran Churches in Scandinavia are also members of the Lutheran World Federation, and adopts a liberal position on homosexuality, viewing it as moral. In 2006, the (Lutheran) Church of Sweden allowed blessings of same-sex unions and permitted gay clergy.
} 
the Orthodox churches, insofar as the level of acceptance for homosexuality in the Protestant Church is significantly higher.

To sum up our hypotheses: The major religious denominations in EU member states have developed varying interpretations of and positions on homosexuality. We assume that these institutional interpretations influence the attitudes of their members; the more homosexuality is interpreted as deviant behaviour and rejected by a particular denomination, the more the members of that denomination will reject homosexuality themselves. Based on our interpretation of the four denominations, we expect support for the EU non-discrimination model by religious orientation to go as follows: People with no religious affiliation will show higher levels of support for non-discrimination toward homosexuals than will members of religious communities; Protestants will show moderate levels of support, and Muslims, Orthodox Christians and Catholics will show the least support.

e. We also assume that the degree of integration into a particular religious institution, as measured by church attendance, influences beliefs on homosexuality (Pickel 2001). All of the denominations in our analysis have legitimized discrimination toward homosexuals to varying degrees at some point in time, and continue to do so to varying extents. We assume that the degree of integration - regardless of the particular denomination - will influence attitudes toward discrimination in the following direction: The less a person is integrated into the daily practices of his or her religious institution, the less he or she is exposed to the official institutional doctrine, and is therefore more likely to support the principle of non-discrimination.

\subsection{Modernization}

The member states of the European Union also differ in terms of their degree of economic modernization. Karl Marx was one of the first to assume a causal relationship between economic living conditions and peoples' values, and most modernization theories are based on this central assumption. It would exceed the scope of this analysis to reconstruct modernization theory with all its facets, critiques, and revisions (see Berger 1996; Knoebl 2003 for overviews). We are uncertain even today as to which factors have contributed to modernization and how to determine the causal relations between them. The result of the modernization process is a one-time historical growth in the economy and in the prosperity of citizens (Maddison 1995: 21). Regardless of how one explains this growth and developing societal prosperity, there exists substantial concurrence among theorists that modernized societies can be described - not explained - by a set of characteristics that altogether form a syndrome (Norris 2002: 20ff; Bell 1973).

As economic prosperity increases through modernization, a change in the citizens' value systems also occurs. According to Ronald Inglehart and his collaborators (Inglehart 1971; 1997; Inglehart \& Norris 2003; Inglehart \& Welzel 2003; 2004; Welzel 
2002), when chances to satisfy material needs increase, a shift from materialist to post-materialist values, or self-expression values, takes place (Inglehart has more recently used the latter term). Materialist values include the following: satisfying economic living conditions, security, national identity, and the exclusion of outsiders. Post-materialist or self-expression values, in contrast, are characterized by the desire for self-fulfillment, an emphasis on freedom, participation, and the tolerance of diversity. "Rising resources mean that there's enough to go around. Newcomers can be accommodated. Foreigners seem much less threatening; ... instead different cultures come to be seen as interesting and stimulating." (Inglehart 2006: 26). Ronald Inglehart interprets discrimination against homosexuals as one type of social exclusion. He shows that existential security tends to make all out-groups, including homosexuals, more acceptable. The societies in our analysis differ in terms of their economic modernization and social prosperity, and according to Inglehart's interpretation, we expect interviewees from economically less-developed countries to express less support for non-discrimination toward homosexuals than respondents from countries with more modernized economies. We measure the degree of a country's economic modernization using the Human Development Index (HDI). The HDI includes three indexes: real GNP per capita, the level of education, and average life expectancy. The data set used also contains a direct measurement for materialistic and post-materialistic value orientations, in that the so-called Inglehart index can be reconstructed from survey items. Apart from the HDI macro-variable, we also take the Materialism/Post-materialism Index into consideration as an individual variable. ${ }^{8}$ We proceed from the hypothesis that post-materialists are more likely to support the idea of non-discrimination than materialists.

Education is another aspect of societal modernization, which increases both possibilities for self-reflection and the likelihood of acquiring a scholarly worldview. Inglehart describes the effect associated with higher levels of education as "cognitive mobilization", in which education increases the likelihood that traditional concepts will be questioned and possibly rejected, rather than being automatically accepted (Inglehart 1990; Dalton 1984). This questioning of tradition also relates to what is considered as a legitimate sexual identity. We assume that more educated interviewees are more likely to support non-discrimination toward homosexuals. We operationalize education using the highest level of schooling completed by the interviewee, measured by an 8-point scale ranging from "inadequately completed elementary education" up to "university with degree/higher education - upper-level tertiary certificate".

\footnotetext{
8 The Inglehart index was formed on from the answers to the following items: "There is a lot of talk these days about what the aims of this country should be for the next ten years. Which of the things would you say is most/next most important: (1) Maintaining order in the nation, (2) Giving people more say in government decisions, (3) Fighting rising prices, (4) Protecting freedom of speech."
} 


\subsection{Age and sex}

We included the respondent's sex as a variable in our analysis. Past studies have shown that women are more tolerant toward homosexuality than men (Langfeldt et al. 1999). The literature explains this difference in the following way (Irvine 1995): Because the term homosexuality is generally associated with homosexual males, heterosexual men are especially prone to distancing themselves. We also took the age of the respondent into account as a final variable in our analysis. Other studies have shown that younger interviewees express higher levels of support for nondiscrimination toward homosexuals than older interviewees (Ester, Halman, and de Moor 1994; Langfeldt et al. 1999). The influence of age on attitudes toward homosexuality is normally interpreted as a cohort effect rather than a life-cycle effect (Hellevik 2002). According to Inglehart, this is the case because elder generations grew up under conditions of material need, whereas younger generations grew up in economically more secure societies. We follow this interpretation, although our data does not allow us to test whether the impact of age can be interpreted as a cohort or as a period effect.

\subsection{Testing the hypotheses}

To test our hypotheses, we first calculated a linear regression using the question "homosexuality can never/always be justified" (as depicted in Diagram 1) as the dependent variable. As a second step, we also calculated a logistic regression with the question about having homosexuals as neighbours (as shown in Diagram 2) as the dependent variable. Due to the hierarchical structure of the data and a slight variation in the effects of individual-level variables between countries (e.g., age has a strong negative effect in all countries except Turkey and Hungary, where the effect is small and insignificant), we constructed hierarchical models to take this random variation into account. However, the results from these hierarchical models did not differ significantly from our simple logistic or linear regression models. Additionally, there is no empirical evidence to suggest that effects of individual level variables are context-dependent; for instance, the effect of Catholic religious affiliation on homosexuality does not depend on the prevalent religious denomination of the country. We therefore prefer to present the results as obtained by the linear and logistic regression models, which are more straightforward and easier to understand. We take account of the statistical problems associated with the hierarchical data structure by estimating robust standard errors.

Both analyses come to very similar results. As the $\mathrm{R}^{2}$-Value and the Pseudo- $\mathrm{R}^{2}-$ Value in Tables 1 and 2 show, we can explain very well attitudes toward nondiscrimination of homosexuals with our theoretically-deduced, independent variables. The independent variables can explain twenty-nine or twenty-eight percent of 
the variance. Furthermore, the signs of the standardized coefficients go in the expected direction (although some not to a significant degree), which largely confirms all of our hypotheses.

a. The variables derived from modernization theory, namely the economic development of country, post-materialistic orientation of respondents, and educational level of interviewees, have the strongest influence on citizens' conceptions of discrimination and go in the expected direction. The more modernized the country, the more likely it becomes that the respondent will support the EU's non-discrimination policy. The respondent's value orientation also affects his or her conception of nondiscrimination, in that post-materialists support the EU's non-discrimination concept more so than materialists. Education also has the expected impact; the higher the respondent's level of education, the more likely he or she is to support the idea of nondiscrimination.

Table 1: $\quad$ Explaining attitudes toward non-discrimination of homosexuality: linear regression

\begin{tabular}{|c|c|}
\hline & "Homosexuality can never/ always be justified" \\
\hline \multicolumn{2}{|l|}{ Religion a) } \\
\hline Protestants & .006 \\
\hline Roman Catholics & $-.076^{*}$ \\
\hline Orthodox & -.031 \\
\hline Muslims & $-.045^{*}$ \\
\hline Integration into church & $-.133^{* * *}$ \\
\hline \multicolumn{2}{|l|}{ Modernisation } \\
\hline HDI & $.354^{* * *}$ \\
\hline $\begin{array}{l}\text { Inglehart-Postmate- } \\
\text { rialism-Index }\end{array}$ & $.121^{* * *}$ \\
\hline Education of respondent & $.133^{* * *}$ \\
\hline \multicolumn{2}{|l|}{ Socio-demographic Variables } \\
\hline Sex of respondent & $.108^{* * *}$ \\
\hline Age of respondent & $-.174^{* * *}$ \\
\hline $\mathbf{R}^{2}$ & .296 \\
\hline
\end{tabular}


Table 2: $\quad$ Explaining attitudes toward non-discrimination of homosexuals: binary logistic regression

\begin{tabular}{lc}
\hline & "Don't like homosexuals as neighbours" \\
\hline Religion a) & 1.067 \\
Protestants & $.843^{*}$ \\
Roman Catholics & .954 \\
Orthodox & $.744^{* * *}$ \\
Muslims & $.788^{* * *}$ \\
$\quad$ Integration into church & \\
Modernisation & $2.209^{* * *}$ \\
HDI & $1.161^{* * *}$ \\
Inglehart-Postmate- & $1.237^{* * *}$ \\
rialism-Index & $1.259^{* * *}$ \\
$\quad$ Education of respondent & $.788^{* * *}$ \\
Socio-demographic Variables & .280 \\
Sex of respondent & \\
Age of respondent & \\
Pseudo R & (according to Nagelkerke)
\end{tabular}

Reported are odds ratios based on standardized variables.

${ }^{*} \mathrm{p}<.05 ;{ }^{* *} \mathrm{p}<.01 ;{ }^{* * *} \mathrm{p}<.001$ based on robust standard errors.

a) Category of reference: people who do not have a religious affiliation.

b. As assumed, all religious affiliations except Protestants exhibit less tolerance toward homosexuality than people with no religious affiliation; however, the impact of this variable is not very strong. In the linear regression analysis and in the logistic regression the variable is not significant for Orthodox Christians. The degree of integration into the religious institution (as measured by attendance) more strongly influences non-discrimination attitudes than does the particular religious denomination to which the interviewee belongs. This is an interesting finding, in that it contradicts Huntington's thesis that different religious worldviews influence the attitudes of their members. Our analysis shows that the particular religious denomination to which someone belongs is not the most important factor; rather, it is the degree of integration that matters. In this light, the low level of support for the EU's nondiscrimination policy in Turkey and in the Enlargement II Orthodox Christian countries has little to do with the inherent substance of their dominant religious systems; rather, this orientation is primarily due to the degree of modernization and the strength of integration into the respective religious institutions. Citizens of Bulgaria, Romania, and Turkey show less support for the EU's blueprint for nondiscrimination due to the low levels of economic modernization and high levels of integration into religious institutions in their countries, particularly in Turkey.

c. The respondent's gender and age has the expected impact on nondiscrimination attitudes as well. Women are more tolerant than men, and younger people are more in favour of non-discrimination than the elderly. The study by Bettina Langfeldt et al. (1999) showed similar findings. 


\section{Conclusion}

The original intention of the European Community was to establish a unified European market. But a free market can only exist when all actors have equal opportunities to participate and nobody is discriminated against. The question of which characteristics and attributes are grounds for discrimination is, however, open to interpretation. Using European Law and EU policies, we first described how EU institutions have expanded the number of characteristics that may be grounds for discrimination, sexual orientation being one of these features. Equality between hetero- and homosexuals was first introduced with the 1999 Treaty of Amsterdam, and is an essential part of the 2000 "Charter of Fundamental Rights of the European Union". With a non-discrimination directive, the European Council specified the legal basis for equality between hetero- and homosexuals.

By analyzing data from the European Values Survey, we found that the majority of European citizens do not support the idea of equal opportunities for homo- and heterosexuals. A sense that homosexuality is justifiable is particularly low in recently-acceded country groups, and is almost nonexistent in Turkey. Clear differences within the country groups exist at the national level as well. Support for nondiscrimination toward homosexuals in countries like Sweden, Denmark and the Netherlands is rather high, whereas support in Ireland, Italy, and Portugal is rather low. The Czech Republic, Slovakia and Slovenia are the only new member states who come close to the mean values in the EU-15. We can therefore conclude that admitting new countries will change the overall culture in the EU, insofar as the proportion of citizens who do not share the EU's non-discrimination concept will increase. The degree to which citizens accept EU regulations is significant in terms of the legitimacy of its policies. Democracies are structurally dependent on the support of their citizens, and a mismatch between an elite project and public opinion can lead to legitimacy problems for EU institutions, as demonstrated by the French and Dutch rejection of the EU Constitution.

According to the results of our causal analysis, modernization will play a crucial role for the question of whether citizens' attitudes will change in the future. We can explain attitudes toward non-discrimination very well with our theoreticallydeduced variables, and found that a high level of modernization, as measured by the HDI, the interviewee's level of education, and post-materialist values had the strongest impact on non-discrimination attitudes. ${ }^{9}$ One may therefore conclude that support for non-discrimination toward homosexuals will increase if new member states

\footnotetext{
${ }_{9}^{9}$ Our findings strengthen the heavily criticized and "obsolete" modernization theory (Knöbl 2001). This theoretical critique is unfounded if the criticized theory continues to have explanatory power and cannot be replaced by other better theories. Our results suggest this is the case, and we see little reason to dispense with modernization theory.
} 
go through a period of modernization similar to that of the old member states and if the modernization process is not too short. EU membership may even accelerate modernization, as was the case for Greece, Portugal, Spain and Ireland (Bornschier et al. 2004, Delhey 2003). These countries were significantly less modernized at the time of their accession, and membership has proven to be conducive to modernization.

Spain is a good illustration of the correlation between modernization and changes in citizens' values. We analyzed the responses to "World Values Survey" item as to whether respondents consider homosexuality to be justified at four points in time (1981, 1990, 1995-97 and 1999-2000). Looking at the distribution of the extreme positions over time, we can see that the percentage of respondents who view homosexuality as justifiable has steadily increased. In 1981, 52.6 percent of Spaniards answered that homosexuality was not justifiable. This number decreased to 39.9 percent in 1990, to 22.4 percent in 1995-97 and finally to 16.7 percent in 1999-2000. Within twenty years, the acceptance rate for homosexuality in Spain fundamentally changed. Furthermore, the Spanish government introduced a legislative draft allowing homosexual marriages in 2004 despite protests by the Catholic Church. Parliament has since approved this law, and same-sex marriages now have the same rights and responsibilities as heterosexual ones. Such legislation would not have been possible without a change in citizens' values. This change was precipitated by modernization in Spain, which was induced by EU membership. If the accession countries and Turkey undergo similar economic modernizations, such value changes may also occur there. However, this depends on a number of factors that are hard to predict. 


\section{References}

Al-Fatiha Foundation (2003) Homosexuality and Same-Sex Acts in Islam, http://www.alfatiha.org/pamphlet.html (17.05.05).

Arts, W. , Halman, L. (ed.) (2004), European Values at the Turn of the Millennium: European Values Studies. Brill Publisher.

Bell, D. (1973) The coming of post-industrial society: A venture of social forecasting. New York: Basic Books.

Berger, J. (1996) Was bedeutet die Modernisierungstheorie wirklich und was wird ihr bloß unterstellt?, Leviathan, 24(1): 45-62.

Bornschier, V., Herkenrath, M., Ziltener, P. (2004) Political and Economic Logic of Western European Integration. A Study of Convergence Comparing Member and Non-member States 1980-98, European Societies 6: 71-96.

Bonini-Baraldi, M. (2004) Combating sexual orientation discrimination in employment: legislation in fifteen EU member states, Report of the European Group of Experts on Combating Sexual Orientation Discrimination, http:/ec.europa.eu/employment_social/fundamental_rights/pdf/aneval/ sexoreulaw.pdf (08.03.07): 7-48.

Dalton, R. J. (1984) Cognitive Mobilization and Partisan Dealignment in Advanced Industrial Democracies, Journal of Politics, 46: 264-284.

Delhey, J. (2003) Europäische Integration, Modernisierung und Konvergenz. Zum Einfluss der EU auf die Konvergenz der Mitgliedsländer, Berliner Journal für Soziologie 13: 565-584.

Duran, K. (1993) Homosexuality and Islam, in: Swidler, A. (Ed.) Homosexuality and World Religions. Valley Forge, Pennsylvania: Trinity Press International: 181-198.

EKD (Evangelische Kirche Deutschlands) (1996) Mit Spannungen leben. Orientierungshilfe des Rates der EKD, http://www.ekd.de/familie/44736.html (08.03.07).

Esmer, Y. (2002) Is there an Islamic Civilization? Comparative Sociology, 1: 265-298.

Ester, P., Halman, L., de Moor, R. (1994) The individualizing society: Value Change in Europe and North America. Tilburg: Tilburg University Press

European Community (2000) Charter of Fundamental Rights of the European Union, 2000/C 364/01, Article III-21, http://www.europarl.europa.eu/charter/pdf/text_en.pdf (08.03.07).

European Council (2000) Council Directive 2000/78/EC of 27 November 2000 establishing a general framework for equal treatment in employment and occupation, 2000: OJ L 303/18,

http://ec.europa.eu/employment_social/news/2001/jul/directive78ec_en.pdf (08.03.07).

European Parliament (2001) Daily Notebook (B5-0264, 0274, 0282, 0300/2001), http://www.europarl.europa.eu/sides/getDoc.do?pubRef=-//EP//TEXT+MOTION+P5-RC-20010264+0+DOC+XML+V0//EN (08.03.07).

European Parliament (2002) Daily Notebook (B5-0411, 0412, 0416, 0422 und 0431/2002), http://www.europarl.europa.eu/sides/getDoc.do?pubRef=-//EP//TEXT+MOTION+P5-RC-20020411+0+DOC+XML+V0//EN (08.03.07).

European Parliament (2004): Hearing of Rocco Buttiglione on October $5^{\text {th }} 2004$, http://www.europarl.europa.eu/sides/getDoc.do?pubRef=-//EP//TEXT+PRESS+NR-200410051+0+DOC+XML+V0//EN\#SECTION4 (08.03.07).

Fuchs, D., Klingemann, H.-D. (2002) Eastward Enlargement of the European Union and the Identity of Europe, West European Politics, 25(2): 19-54.

Gerhards, J. (2007) Cultural Overstretch? The enlargement of the European Union and the cultural differences between old and new member states and Turkey. London und New York: Routledge (in press).

Gerhards, J., Hölscher, M. (2003) Kulturelle Unterschiede zwischen Mitglieds- und Beitrittsländern der EU. Das Beispiel Familien- und Gleichberechtigungsvorstellungen, Zeitschrift für Soziologie, 32: 206-225.

Gerhards, J., Lengfeld, H. (2006) Das Ökologieskript der Europäischen Union und seine Akzeptanz in den Mitglieds- und Beitrittsländern der EU, Zeitschrift für Soziologie, 35: 24-40. 
Gerhards, J., unter Mitarbeit von M. Hölscher (2005) Kulturelle Unterschiede in der europäischen Union. Ein Vergleich zwischen Mitgliedsländern, Beitrittskandidaten und der Türkei. Wiesbaden: VS Verlag.

Halman, L. (2001) The European Values Study: A Third Wave. Source Book of the 1999/2000 European Values Study Surveys, Tilburg: WORC.

Hellevik, O. (2002) Age Differences in Value Orientation. Life Cycle or Cohort Effects? International Journal of Public Opinion Research, 14: 286-302

Hölscher, M. (2006) Wirtschaftskulturen in der erweiterten EU. Die Einstellungen der Bürgerinnen und Bürger im europäischen Vergleich. Wiesbaden: VS Verlag.

Hopko, F. T. (1987) The Homosexual Christian. Orthodox Research Institute, http://www.orthodoxresearchinstitute.org/articles/ethics/hopko_homosexual_christian.htm (08.03.07).

Human Rights Watch (1988) Public Scandals. Sexual Orientation and Criminal Law in Romania. A Report by Human Rights Watch and the International Gay and Lesbian Human Rights Commission, http://www.hrw.org/reports97/romania (08.03.07).

Huntington, S. P. (1996) The Clash of Civilizations and the Remaking of World Order. New York: Simon \& Schuster.

Inglehart, R. (1971) The Silent Revolution in Europe, American Political Science Review, 65: 991-1017.

Inglehart, R. (1990) Cultural Shift in Advanced Industrial Society. Princeton: Princeton University Press.

Inglehart, R. (1997) Modernization and Postmodernization. Cultural, Economic, and Political Change in 43 Societies. Princeton: Princeton University Press.

Inglehart, R. (2006) Changing Norms: Existential security leads to growing acceptance of out-groups, WZB-Mitteilungen, 113: 26-29.

Inglehart, R., Norris, P. (2003) The True Clash of Civilizations, Foreign Policy, March/April: 67-74.

Inglehart, R., Welzel, C. (2003) Political Culture and Democracy: Analyzing Cross-Level Linkages, Comparative Politics, 36: 61-81.

Inglehart, R., Welzel, C. (2004) Modernization, Cultural Change and Democracy. The Human Development Sequence. Cambridge: Cambridge University Press.

Irvine, J. M. (1995) Sexuality Education Across Cultures: Working with Differences. San Franciso: JosseyBass.

Kelley, J. (2001) Attitudes toward homosexuality in 29 nations, Australian Social Monitor, 4(1): 15-22.

Knöbl, W. (2003) Theories that Won't Pass Away: The Never Ending Story of Modernization Theory', in: Delanty, G. and Engin F. Isin (Eds.) Handbook of Historical Sociology, London: Sage: 96-107.

Langfeldt, B., Braun, M., Lewin-Epstein, N., Stier, H. (1999) Sexuelle Permissivität: Ein DeutschIsraelischer Vergleich, ZUMA-Nachrichten 44(23): 108-129.

Laumann, E. O., Gagnon, J. H., Michael, R. T. and Michaels, S. (1994) The Social Organization of Sexuality. Sexual Practices in the United States. Chicago / London: The University of Chicago Press.

Maddison, A. (1995) Monitoring the World Economy 1820-1992, Development Centre of the Organisation for Economic Co-operation and Development, Paris: Development Centre of the Organisation for Economic Co-operation and Development.

Mohr, A. I. (2003) Das Volk Lots und die Jünglinge des Paradieses. Zur Homosexualität in der Religion des Islam, in: Bochow, M. and Marbach, R. (Eds.) Homosexualität und Islam. Hamburg: MännerschwarmSkript: 51-84.

Norris, P. (2002) Democratic Phoenix. Cambridge: Cambridge University Press.

Page, B. I., Shapiro, R. Y. (1983) Effects of Public Opinion on Policy, American Political Science Review, 77: 175-190.

Pickel, G. (2001) Moralische Vorstellungen und ihre religiöse Fundierung im europäischen Vergleich, in: Pickel, G. and Krüggeler, M. (Eds.) Religion und Moral. Entkoppelt oder verknüpft? Opladen: Leske + Budrich: 105-134.

Robinson, B.A. (2002) Islam and Homosexuality, http://www.religioustolerance.org/hom_isla.htm (17.05.2005) 
Snow, D.A., Benford, R.D. (1988) Ideology, Frame Resonance, and Participant Mobilization, in: Klandermans, B., Kriesi, H. and Tarrow, S. (Eds.) International Social Movement Research 1. Greenwich, Connecticut: JAI Press: 197-217.

Snow, D.A., Rochford, E.B., Worden, S.K., Benford, R.D. (1986) Frame Alignment Processes, Micromobilization, and Movement Participation, American Sociological Review, 51: 464-481.

Stone Sweet, A., Sandtholtz, W., Fligstein, N. (Eds.) (2001) The Institutionlization of Europe. Oxford: Oxford University Press.

Vatican (2003) Congregation for the doctrine of the faith: Considerations regarding proposals to give legal recognition to unions between homosexual persons, http://www.vatican.va/roman_curia/congregations/ cfaith/documents/rc_con_cfaith_doc_20030731_homosexual-unions_en.html (08.03.07).

Welzel, C. (2002) Fluchtpunkt Humanentwicklung. Über die Grundlagen der Demokratie und die Ursachen ihrer Ausbreitung, Wiesbaden: Westdeutscher Verlag.

Wessels, W. (1997) An Ever Closer Fusion? A Dynamic Macropolitical View on Integration Processes, Journal of Common Market Studies, 35: 267-299. 